\title{
IS SUGAR SWEETER AT THE PUMP? THE MACROECONOMIC IMPACT OF BRAZIL'S ALTERNATIVE ENERGY PROGRAM
}

\author{
Marc D. Weidenmier \\ Joseph H. Davis \\ Roger Aliaga-Diaz \\ Working Paper 14362 \\ http://www.nber.org/papers/w14362
}

\author{
NATIONAL BUREAU OF ECONOMIC RESEARCH \\ 1050 Massachusetts Avenue \\ Cambridge, MA 02138 \\ October 2008
}

The authors would like to thank Arevik Avedian, Clement Ogbomo and Lindsay Fay for excellent research assistance. The views expressed in this paper do not necessarily reflect the opinions of The Vanguard Group, nor those of the National Bureau of Economic Research.

NBER working papers are circulated for discussion and comment purposes. They have not been peerreviewed or been subject to the review by the NBER Board of Directors that accompanies official NBER publications.

(C) 2008 by Marc D. Weidenmier, Joseph H. Davis, and Roger Aliaga-Diaz. All rights reserved. Short sections of text, not to exceed two paragraphs, may be quoted without explicit permission provided that full credit, including $(\mathcal{O}$ notice, is given to the source. 
Is Sugar Sweeter at the Pump? The Macroeconomic Impact of Brazil's Alternative Energy

Program

Marc D. Weidenmier, Joseph H. Davis, and Roger Aliaga-Diaz

NBER Working Paper No. 14362

September 2008

JEL No. E3,N1

\begin{abstract}
The recent world energy crisis raises serious questions about the extent to which the United States should increase domestic oil production and develop alternative sources of energy. We examine the energy developments in Brazil as an important experiment. Brazil has reduced its share of imported oil more than any other major economy in the world in the last 30 years, from 70 percent in the 1970s to only 10 percent today. Brazil has largely achieved this goal by: (1) increasing domestic oil production and (2) developing one of the world's largest and most competitive sources of renewable energy -sugarcane ethanol -- that now accounts for 50 percent of Brazil's total gasoline consumption. A counterfactual analysis of economic growth in Brazil from 1980-2008 suggests that GDP is almost 35 percent higher today because of increased domestic oil production and the development of sugarcane ethanol. We also find a notable reduction in business-cycle volatility as a result of Brazil's progression to a more diversified energy program. Nearly three-fourths of the welfare benefits have come from domestic oil drilling, however, as rents have been paid to domestic factors of production during a time of rising oil prices. We discuss the potential implications of Brazil's energy program for the U.S. economy by conducting historical counterfactual exercises on U.S. real GDP growth since the 1970s.
\end{abstract}

Marc D. Weidenmier

Department of Economics

Claremont McKenna College

Claremont, CA 91711

and NBER

marc_weidenmier@claremontmckenna.edu

Joseph H. Davis

The Vanguard Group

P.O. Box 2600, MS V37

Valley Forge, PA 19482-2600

and NBER

joseph_davis@vanguard.com
Roger Aliaga-Diaz

The Vanguard Group

P.O. Box 2600, MS V37

Valley Forge, PA 19482-2600

roger_aliaga-diaz@vanguard.com 
The recent global energy crisis raises many questions about the extent to which the United States should increase domestic oil and fossil fuel production as well as develop alternative renewable sources of energy such as biofuels, wind, and solar power. Proponents of drilling and fossil fuel production argue that existing technology has not advanced to the point where alternative sources of energy can significantly reduce American dependence on fossil fuels. Supporters of increased domestic oil production will also point out that rents largely go to domestic factors of production as opposed to foreign countries. Critics of domestic oil production argue that fossil fuels are destroying the environment and play a key role in global warming by increasing the amount of carbon in the atmosphere (see DiPeso, 2003, Pickens, 2008; Johnson, 2008).

As shown by the current Presidential Election, one of the major challenges for American policymakers is to develop a sensible energy policy that weighs the costs and benefits of increased domestic oil production against cleaner, renewable alternative energy sources. This is a difficult economic question for two reasons. First, there is little empirical evidence on the effects of significantly reducing the share of imported oil on economic growth. As shown in Table 1, the lack of empirical evidence on this question can probably be attributed to the fact that the share of oil imported as a fraction of total oil consumption and production by the G7 economies has not changed very much since the 1970s. Second, renewable energy sources account for about approximately one percent of energy consumption in the G7 economies.

Fortunately, Brazil provides a historical experiment to examine the economic effects of dramatically reducing a country's share of imported oil as well as the impact of an important alternative energy program. As shown in Figure 1, Brazil has reduced its share of imported oil from about 70 to 10 percent over the last 30 years, more than any other major economy in the 
world. The South American country has largely achieved this goal by increasing domestic oil production and developing the world's largest clean renewable alternative energy source that competes directly with gasoline at the pump, sugarcane ethanol. Figure 2 shows that the clean renewable alternative energy source currently accounts for over half of fuel demand in Brazil and more than 23 percent of Brazil's combined consumption of fossil and ethanol fuel (IPEA, various issues).

We examine the effects of Brazil’s energy policies on its economic growth since 1980 by extending models developed by Hamilton (1996, 2003) and Killian (2008a, 2008b, 2008c) to include a country's share of oil imports as a fraction of total oil consumption and production. The empirical analysis suggests that real GDP is approximately 35 percent higher in Brazil because the country has reduced its share of imported oil by increasing domestic oil production and developing sugarcane ethanol so that rents go to domestic factors of production. We also find a reduction in business-cycle volatility in the range of 14-22 percent as a result of Brazil's energy policies, with the most significant reductions coming over the past decade. We find that approximately three-fourths of the welfare benefits are a direct result of increasing domestic oil production during a period when oil prices have risen sharply. ${ }^{1}$

Brazil's energy programs raise important questions about the extent to which the United States should increase domestic oil production and develop alternative sources of energy. Since alternative energy sources in the U.S. account at the present time for only a small percentage of total energy consumption, we cannot specifically address this policy question. However, we can examine the hypothetical historical impact to the U.S. economy had the United States aggressively drilled all of the nation's oil and natural gas reserves. What would have been the

\footnotetext{
${ }^{1}$ Sugarcane ethanol is much cleaner than gasoline and has significant environmental benefits. We focus on the effects of Brazil's sugarcane policy on economic growth and leave an analysis of the environmental impact for future research.
} 
economic benefits? Would they have been sufficient to offset the negative effects of oil shocks on U.S. economic activity? Would they have been sufficient to (at least temporarily) have made the country "energy independent?"

To consider this possibility, we simulate U.S. economic growth over the last 30 years under the (admittedly controversial) assumption that oil companies were allowed to drill in ANWR and the public lands. A recent Bureau of Land Management Report to Congress (2008) estimates that opening up the public lands to oil and natural gas production could yield as much as 77 billion barrels of oil (and oil-barrel equivalents). We find that eliminating drilling restrictions on the public lands would have raised US GDP by approximately 11 percent, or 1.5 trillion dollars in 2005(USD), over the last 33 years. However, we interpret these economic benefits as an "upper bound" estimate since the counterfactual exercise assumes that the nation's improvements in energy intensity (oil consumed per unit of real GDP) was unaffected by this radical change in domestic oil production. Under an alternative (and admittedly strong) assumption that the nation's energy intensity in 1977 would have remained constant through 2008, then the increases in domestic fossil fuel production would have yielded a more modest cumulative increase of approximately seven to eight percent in the level of U.S. real GDP by the first quarter of 2008.

Although our counterfactual results suggest that increased domestic fossil fuel production could potentially have large economic benefits for the United States in the next 20 to 30 years, the exercise also clearly demonstrates that the United States can not permanently drill its way to “energy independence.” Alternative sources of energy (whether they be nuclear, wind, solar, or bio-fuels) will eventually be needed so that the United States can more effectively reduce the economy's exposure to the negative effects of imported oil shocks. 
We begin the analysis with a brief history of Brazil's oil and sugarcane ethanol policies. This is followed by an empirical analysis of oil and ethanol shocks on Brazilian economic growth controlling for the percent of oil imported from foreign countries. Then we discuss the implications of the Brazilian experience for the United States. This is followed by a counterfactual analysis of US economic growth under the assumption that the public lands were opened for drilling by the US government in the late 1970s. We conclude with a discussion of the implication of the results for the U.S. economy.

\section{A Brief History of Brazil's Energy Policy, 1975-2008}

\section{A. Sugarcane Ethanol Program}

The Brazilian economy experienced rapid economic growth in the late 1960s and early 1970s until the onset of the oil supply shocks. The 1973 oil shocks created two economic problems for Brazil: (1) the cost of its oil imports—which constituted almost 80 percent of domestic oil consumption — tripled in late 1973 because of the Arab oil embargo and (2) world sugar prices declined sharply in 1974. The 1973 oil shock produced a large recession in Brazil As a result, President Geisel launched the Programa Nacional do Álcool (National Alcohol Program) or Pró-Álcool November 14, 1975. The program was designed to increase the production of alcohol from sugar cane, modernizing and expanding existing distilleries, and developing new production units. The program was intended to take advantage of the country's comparative advantage in producing sugarcane because of its tropical climate (Renato, 2007).

Pró-Álcool provided tax incentives to expand the sugar industry and was backed by public and private sector investments. The Brazilian government launched a marketing program 
with the slogan "Let's unite, make alcohol.” Brazil required Petrobras, the country's semi-public oil monopoly to purchase and distribute sugarcane ethanol. The government offered low-interest loans and credit guarantees for the construction of new refineries and taxed gasoline at a higher rate at the pump. The government also mandated that transportation fuel be blended with a minimum of 22 percent ethanol (Schmitz et al., 2007).

The results were dramatic. Between 1975 and 1979, ethanol production increased more than 500 percent. The second stage of the program was launched in 1979, when the Brazilian government signed agreements with major car companies to produce vehicles that ran on 100 percent ethanol. Fiat, Volkswagen, Mercedes-Benz, General Motors and Toyota agreed to produce 250,000 ethanol-only cars in 1980 and 350,000 in 1982. The government program even subsidized taxi drivers to purchase ethanol-only cars (Lashinsky and Schwartz, 2006).

During the early 1980's, Brazil's ethanol program flourished with high oil prices, government intervention, and a World Bank loan that covered a portion of the costs. Between 1979 and 1985, ethanol production more than tripled in Brazil. The alternative fuel program began to experience serious problems in the mid-1980s, however, as oil prices began to fall and sugar prices started to rise. Nevertheless, automakers in Brazil continued to manufacture ethanolonly cars in increasing amounts given the incentive system provided by the government. By the late 1980's, almost all new cars in Brazil were running on ethanol which produced a shortage of the alternative fuel. Ironically, Brazil was forced to import ethanol and turn to a methanol blends to keep ethanol-only cars on the road (Renato, 2007).

Political support for Pró-Álcool began to wane as oil prices declined in real and nominal terms in the late 1980s and early 1990s. Ethanol production became less attractive which forced the government to subsidize the producers via Petrobras. The government cut soft loans for the 
construction of new ethanol refineries, and support for the ethanol program from state trading companies was reduced and ultimately eliminated. Brazilian auto manufacturers retooled and began to build gasoline cars again. By the mid-1990's, the government only required fleet vehicles (such as taxis and rental cars) to run on ethanol.

The Brazilian government made several changes to its sugarcane ethanol program in 1998. Petrobras' monopoly over the distribution of ethanol was eliminated and ethanol prices were no longer controlled by the government. Subsidies to the ethanol sector were largely eliminated although the government continues to tax ethanol at a much lower rate at the pump. Brazilian also regulates the percentage of ethanol in gasoline. Brazil increased the alcohol content of gasoline from 20 to 22 percent in May 2001 and to 24 percent in June 2002. The energy authorities apparently raise (lower) the blending rate when oil prices are high (low) and sugar prices are relatively low (high) (Schmitz et al., 2007).

The introduction of new technologies in the last several years appears to be making sugarcane ethanol a more viable alternative energy source. Ford introduced flex-fuel cars in 2002, followed by Volkswagen in 2003. Flex-fuel cars can operate on ethanol, gasoline or any blend of the two fuels. The government creates incentives for consumers to purchase flex-fuel cars by offering buyers a two percent lower sales tax compared to automobiles that run on gasoline. In 2004, production of the flex-fuel cars increased to 328,300 and reached 5 million by March of 2008. Approximately 90 percent of all new cars produced in Brazil are flex-fuel (Associação Nacional dos Fabricantes de Veículos Automotores, 2007, 2008). This trend will probably continue unless oil prices significantly decline in the coming years. 


\section{B. Domestic Oil Policy}

Brazil recognized that ethanol could not solve the country’s energy problems. To boost domestic oil production and reduce fossil fuel demand, the Brazilian government kept oil prices artificially high in the 1980s to help fund oil exploration and drilling by Petrobras, the country’s semi-public oil monopoly. Between 1980 and 2005, Brazil increased domestic crude oil production on average of more than nine percent a year from, to 1.6 million barrels of oil per day.

In the last couple of years, Petrobras has discovered huge oil deposits off the coasts of Rio de Janiero and Sao Paolo that could increase the country's oil reserves by more than 40 billion barrels. ${ }^{2}$ The government has also recently eliminated Petrobas’ oil monopoly in Brazil, forcing the company to compete in the global marketplace. Reducing its dependence on oil imports has long been a political priority in Brazil, where oil dependence was as high as 85 percent of its energy consumption in 1979 and plummeted to about 10 percent in $2002 .^{3}$ Many analysts believe that increased production and new oil discoveries have played the most important role in reducing the country’s oil import share because rents go to domestic factors of production rather than abroad, especially when oil prices are high. ${ }^{4}$ We now turn to the empirical analysis to test the effects of the two energy programs on Brazilian economic growth over the last 30 years.

\footnotetext{
${ }^{2}$ BBC news http://news.bbc.co.uk/2/hi/business/7348111.stm.

${ }^{3}$ EIA, 2008.

${ }^{4}$ http://www.brazzilmag.com/content/view/9232/
} 


\section{Empirical Analysis}

To analyze the economic effects of Brazil’s energy policies, we initially employ models developed by Hamilton $(1996,2003) .{ }^{5}$ The general form of the model can be written as:

$$
y_{t}=\alpha+\sum_{i=1}^{L} \beta_{i} y_{t-i}+\sum_{i=1}^{L} \gamma_{i} o_{t-i}+\varepsilon_{t}
$$

where $y_{t}$ is real GDP growth (or any measure of economic activity) in quarter $\mathrm{t}$, reported at a quarterly rate and $\mathrm{o}_{\mathrm{t}}$ is an oil price shock. Endogeneity is a potential problem in Equation (1) as real GDP growth may cause changes in oil prices and changes in oil prices may cause real GDP growth. Hamilton (1996) proposed a solution to solve the endogeneity problem by transforming the oil price series to identify large oil shocks that can be attributed to well-known exogenous such as geopolitical developments (in the Middle-East) that disrupt the world oil supply. Hamilton suggests that oil shocks should be calculated as the percentage change in prices relative to the price peak reached during the last year (if the shock is negative, then it is set to zero): ${ }^{6}$

$o_{t}=\operatorname{MAX}\left[0, \log \left(p o_{t}\right)-\log \left(M A X\left(p o_{t-1}, p o_{t-2}, \ldots, p o_{t-12}\right)\right)\right]$

where $p o_{t}$ is oil prices, here measured by real West Texas Intermediate prices in US Dollars and deflated by US CPI.

\footnotetext{
${ }^{5}$ For an analysis of the effects of oil shocks on economic activity using Granger-causality tests and linear regressions, see Hamilton (1983, 1985, 1996, 2003), Mort (1989). Hooker (1996) argues that there is a structural break in the effect of oil price changes on the macroeconomy. For a discussion of oil shocks and monetary policy, see Bernanke (2004) and Bernanke et. al (1997). Hooker (2002) analyzes the inflationary effects of oil shocks.

${ }^{6}$ Hamilton (2003) shows that the spikes in the transformed series coincide indeed with geopolitical events known to have resulted in disruptions in the world supply of oil.
} 
In Brazil, where alternative energy sources are widely used, energy-cost shocks are driven not only by changes in prices of each source (oil or ethanol) but also by the incidence of each energy source in the total cost of energy bore by the consumers. To account for both sources of energy, we modify Hamilton's definition of an energy shock to include ethanol, $e_{t}$

$e_{t}=\operatorname{MAX}\left[0, \log \left(p e_{t}\right)-\log \left(\operatorname{MAX}\left(p e_{t-1}, p e_{t-2}, \ldots, p e_{t-12}\right)\right)\right]$

where $p e_{t}$ is ethanol prices.

Annual ethanol prices are interpolated into higher frequency data using monthly sugar cane prices (the key input into ethanol production). Sugar cane prices are compiled by Fundacion Getulio-Vargas (FGV) and made available through Brazil’s IPEA database. The final quarterly ethanol price series is deflated by Brazil's GDP deflator. To account for oil and ethanol's fraction of total energy use, we combine the two individual oil and ethanol price shocks into a single energy shock variable:

$s_{t}=o_{t} \times\left(1-w_{t}\right)+e_{t} \times w_{t}$

where $w_{t}$ is ethanol's share of Brazil's total consumption of ethanol and oil-derived products in barrels. In our regressions, we also include a dummy variable $\left(D_{t}\right)$ to account for Brazil’s macroeconomic stabilization program following the country's high-inflation and hyperinflation

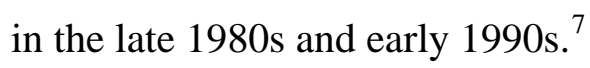

The model can now be written as:

$$
y_{t}=\alpha+\sum_{i=1}^{L} \beta_{i} y_{t-i}+\sum_{i=1}^{L} \gamma_{i} s_{t-i}+\delta_{i} D_{t}+\varepsilon_{t}
$$

\footnotetext{
${ }^{7}$ We set the dummy variable to 1 if annual inflation rate is below $15 \%$. This dummy takes value 1 for most of the period post-July 1994, the year in which Brazil successfully implemented the stabilization program known as "Plan Real”. We also tested to see if there was a structural break at this known date. Using a Chow test, we were unable to reject the null hypothesis of no structural break.
} 
Quarterly GDP data for Brazil are taken from the official statistics of the South American country, IPEA. ${ }^{8}$ The sample covers the period January $1980-2008 .{ }^{9}$ The results for the baseline Hamilton specification are reported in Column 1 of Table 2. The F-statistics shows that oil shocks in Brazil do not have a statistically significant effect on economic activity in the South American country.

One problem with the baseline regression is that the analysis does not control for the large change in Brazil's oil import share over time. This might explain why oil shocks do not have a statistically significant effect on Brazil's real GDP growth. To consider this possibility, we weight the energy shocks by the percent of oil and ethanol imported into Brazil. The "normalized" net import coefficient for oil and ethanol is defined as $m_{t}^{\text {oil,ethanol }}=$ (consumption production) / (consumption + production) and $m_{t}^{\text {oil, ethanol }} \in[-1,1]$. If the normalized net import coefficient took a value of one, this would indicate that all oil/ethanol consumed is being imported and there is no domestic production. As shown in Figure 1, Brazil has drastically reduced its dependency on foreign oil in the period 1975-2008. In order to account for the changing degree of foreign oil dependence in our energy shock variable we modify (4) as follows:

$s_{t}^{m}=o_{t} \times\left(1-w_{t}\right) \times m_{t}^{o}+e_{t} \times w_{t} \times m_{t}^{e}$

We then re-estimate model (5) with $\mathrm{s}_{\mathrm{t}}^{\mathrm{m}}$ substituted for $\mathrm{s}_{\mathrm{t}}$. The results are reported in Column 2 of Table 1. Peak oil shocks, adjusted for the percent of oil imported, are now jointly significant at

\footnotetext{
${ }^{8}$ www.ipea.gov.br

${ }^{9}$ We would like to include the 1970s in the analysis since the historical record suggests that oil shocks had a particularly large negative effect on Brazil. Unfortunately, quarterly GDP data, quarterly ethanol consumption and quarterly ethanol production data for Brazil are not available for the 1970s. If the 1970s oil shocks had large negative effects on Brazil, then our results would provide a lower bound estimate on the gains from domestic energy production in the South American country.
} 
the 3 percent level. This suggests that reducing the oil import share has reduced the negative effects of oil shocks. Rents paid to domestic factors of energy production offset the effects of peak oil on economic activity. Indeed, as shown in Figure 3, the effect of oil shocks on real GDP growth in Brazil has fallen by approximately 80 percent since 1980, from .1 to .02 percent.

Finally, we define a third type of energy shock that controls for energy intensity. We multiply our energy shock variable by a measure of energy intensity that is defined as total barrels of oil and ethanol combined per unit of real GDP (ethanol consumption was converted to oil-equivalent quantities based on ethanol BTU equivalence to oil). ${ }^{10}$ If we define as $i_{t}$ the energy intensity coefficient, our specification (5) becomes:

$$
y_{t}=\alpha+\sum_{i=1}^{L} \beta_{i} y_{t-i}+\sum_{i=1}^{L} \gamma_{i} s_{t-i}^{m} i_{t-i}+\delta_{i} D_{t}+\varepsilon_{t}
$$

As shown in Column 3 of Table 2, the energy shocks weighted by intensity are jointly significant at the 2 percent level. The magnitude of the energy shocks is approximately the same size as the energy shocks reported in Column 2 of Table 2.

The basic idea behind equations (1)-(5’) is to estimate the response of economic activity to exogenous changes in the prices of oil and ethanol. Kilian (2008a, 2008b, forthcoming) argues that Hamilton's (1996) non-linear transformation of oil price shocks defined in equation (2) does not adequately identify supply and demand shocks. ${ }^{11}$ Oil price shocks respond primarily to precautionary demand shocks rather than to supply shocks. Precautionary demand price changes are triggered by commercial users of oil who want to hedge against the possibility of an oil

\footnotetext{
${ }^{10}$ Ethanol's energy content is $76330 \mathrm{BTU} / \mathrm{gal}$ or $3205859.919 \mathrm{BTU} / \mathrm{bbl}$ of ethanol (1bbl = 42 gal). For gasoline, $116090 \mathrm{BTU} / \mathrm{gal}$. Since $19.2 \mathrm{gal}$ of gasoline can be refined from $1 \mathrm{bbl}$ of oil; so $116090 * 19.2=2228928 \mathrm{BTU} / \mathrm{bbl}$ of oil. So the conversion coefficient is approximately $1.44 \mathrm{bbl}$ of oil per bbl of ethanol (3205859.919 / 2228928).

${ }^{11}$ Endogeneity bias would lead to inconsistent estimation of the parameters in [1]-[3]. Suppose that oil and ethanol prices are driven by demand and supply shocks in oil and ethanol markets, respectively. Suppose further, that these supply and demand shocks impact Brazil GDP both directly and indirectly via oil and ethanol prices (see Kilian, forthcoming). Then, the residuals would then be correlated with the oil or ethanol price shocks, violating a key assumption for OLS.
} 
shortage in the future (and by speculators in search of a profit under the belief that oil will be relatively scarce in the future). Therefore, Killian argues that it is necessary to disentangle precautionary demand from ordinary current crude oil demand.

We adopt Kilian’s (forthcoming) three-variable structural (SVAR) specification to separately identify oil supply and demand shocks, with the exception that we apply Hamilton's transformation after removing global demand shocks from the analysis to identify peak oil shocks. The three-variable system includes the percentage change in oil production, a de-trended global economic activity indicator, and the percentage changes in real oil prices. For the global economic activity indicator, we use the Baltic Exchange Dry Index from Datastream. ${ }^{12}$ World oil prices are proxied by West Texas Intermediate spot prices deflated by the US consumer price index. Our sample period covers quarterly data from January 1975 to March 2008. We allow for twelve lags in the VAR specification to capture the dynamics in the system.

Following Kilian (forthcoming) we impose two identifying restrictions to uncover the structural shocks from the reduced form VAR. First, unanticipated oil-production shocks (i.e. the residuals of the oil-production equation in the VAR) are driven by supply-side decisions. This means that oil producers can not respond to higher oil prices (even if they wanted to) or to speculative trading by investors in a period as short as a month. Second, unanticipated changes in global demand (i.e. the residuals of the global demand equation in the VAR) are unlikely to be caused by unexpected oil prices changes taking place within the same month. Global demand is also unlikely to be affected by speculation shocks either. With these identifying restrictions, we can recursively identify oil supply and demand shocks using a standard Choleski decomposition.

The model can be written as follows:

\footnotetext{
${ }^{12}$ The Baltic index is available since May 1985. We extend the series back to January 1975 using OECD world industrial production index, from Datastream. Kilian (forthcoming) reports his results remain unaltered when using OECD world industrial production instead of his preferred global economic activity indicator.
} 


$$
\left[\begin{array}{c}
\varepsilon_{\text {production }} \\
\varepsilon_{\text {econ.activity }} \\
\varepsilon_{\text {oil_price }}
\end{array}\right]=\left[\begin{array}{ccc}
a_{11} & 0 & 0 \\
a_{21} & a_{22} & 0 \\
a_{31} & a_{32} & a_{33}
\end{array}\right] \times\left[\begin{array}{c}
v_{\text {oil_sup ply }} \\
v_{\text {g.demand }} \\
v_{\text {prec_demand }}
\end{array}\right]
$$

The $\varepsilon$ are the unexpected shocks (or the residuals) from the regular reduced-form three variable VAR system and the $v$ 's are the unobserved structural shocks. The underlying structural shocks can be identified using the recursive identification scheme. Figure A1, in the appendix, displays the oil-price series resulting from the estimated SVAR, which excludes exogenous global demand shocks.

Table 3 displays regression output for models (5) and (5’) but based on applying an analogous to Hamilton's transformation (equation 2) to this oil-price series (we label this model “Kilian specification”, since it is based on Kilian’s SVAR identification of exogenous oil shocks). The results reported in Table 3 are quite similar to the analysis using the standard Hamilton’s transformation. Column 1 of Table 3 shows that an oil shock does not have a statistically significant effect on economic growth. However, oil shocks reduce real GDP growth in Brazil once we weight oil shocks by the oil import share and energy intensity. The weighted energy shocks are statistically significant at the one percent level in Columns 2 and 3 of Table 3. By increasing domestic production, Brazil has reduced the negative effects of oil shocks. As shown in Figure 4B, the time-varying impact of oil shocks has also fallen around 80 percent for Brazil in the Kilian specification, from .12 percent to almost .02 percent.

\section{Counterfactual exercises for Brazil}

Hamilton (2003) runs a regression similar to equation (1) for the United States using peak oil shocks defined in equation (2). He then conducts simple counterfactual exercises based on 
setting $\mathrm{o}_{\mathrm{t}}=0$. That is, what would have been U.S. GDP growth there had been no oil shocks during the sample period? The difference between the counterfactual fitted values (with $\mathrm{o}_{\mathrm{t}}=0$ ) and the true fitted values is a measure of the GDP growth gain the country would have experienced there had been no oil shocks.

For Brazil, we believe that the appropriate counterfactual analysis is to assume no ethanol program and no change in the net oil import share since the late 1970s. We perform the counterfactual analysis using our Hamilton and Killian specifications. This counterfactual scenario implies to set $w_{t}=0$ (and thus $s_{t}^{m}=o_{t} \times m_{t}^{o}$ ) and $m_{t}^{o}=m_{1980}^{o+e} \cdot m_{1980}^{o+e}$ is the net import coefficient, as of 1980:Q1, that arises from the total oil plus ethanol combined consumption (based on ethanol's BTU oil-equivalence). The difference between the counterfactual fitted values and the true fitted values is a measure of the GDP growth loss Brazil would have experienced under the proposed scenario of no ethanol program and neglecting the impact of discoveries of oil. As shown in Figures 5A (Hamilton counterfactual) and 5B (Killian counterfactual), Brazil's energy program suggests that GDP would be approximately 30 and 35 percent lower in Brazil if the country did not reduce its share of imported oil by increasing domestic energy production (oil and sugarcane ethanol) since 1980. The large welfare gains suggest that increased domestic energy production (oil and sugarcane ethanol) has largely offset the negative effects of oil shocks because rents are now paid to domestic factors (rather than foreign factors).

We then run a second counterfactual scenario that keeps the assumption of no ethanol program but it allows for new discoveries of oil during the sample period. That is, we now set $w_{t}=0$ (and thus $s_{t}^{m}=o_{t} \times m_{t}^{o}$ ) and $m_{t}^{o}=m_{t}^{o+e}$. Thus, we let $m_{t}^{o+e}$ to change through time according to Brazil’s increasing production of oil, but accounting for the extra oil consumption 
needed to make up for the lost ethanol production (again, based on ethanol's BTU oilequivalence). The difference between counterfactual and actual fitted values in (5') is the GDP growth loss Brazil would have experienced without the Pro-Álcool program.

Finally, the difference between the two counterfactuals can be interpreted as the GDP loss resulting only from new oil discoveries. The simulations show that approximately three-quarters of the welfare gains actually experienced by Brazil (relative to the counterfactual scenario) can be attributed to an increase in domestic oil discoveries rather than to Brazil's sugarcane ethanol program. Still, our results indicate that sugarcane ethanol has been successful in helping to partially insulate Brazil’s economy from imported oil shocks. ${ }^{13}$ Under the counterfactual case of no ethanol program, the level of Brazil’s real GDP would be approximately 8 percent lower.

In evaluating the macroeconomic and welfare effects of Brazil's reduced foreign oil dependence, it is also important to examine the potential business cycle effects of Brazil's energy policy. An example would include mitigating the impact of terms-of-trade shocks on output volatility, as Brazil is a price-taker in world oil markets. Assuming reasonable levels of risk aversion for Brazilian households, and to the extent that liquidity constraints and market imperfections prevent households from perfectly smoothing consumption, welfare would be unambiguously increased if output volatility is lower.

Table 4 compares Brazil's historical GDP growth volatility against output volatility under the two counterfactual scenarios described before. Since 1980, Brazil has been able to reduce average output volatility (as defined by the standard deviation in quarterly real GDP growth) by approximately 14 to 22 percent. Since 1995, business-cycle volatility has been reduced by as much as 33 percent using the Kilian derivation for exogenous oil-price shocks.

\footnotetext{
${ }^{13}$ Sugarcane ethanol has also reduced air pollution in Brazil's major cities. The environmental benefits of sugarcane ethanol are not considered in this paper. We leave this as an item for future research.
} 


\section{Counterfactual exercises for the United States}

The success of Brazil energy program raises important questions about the economic effects of reducing the oil import share in the United States by increasing domestic production of fossil fuels and developing alternative sources of energy. As shown in Figure 6, the oil import share for the United States has risen from about 40 to 60 percent in the last 30 years. The rise in the share of oil imports has been partially offset by a decrease in energy intensity, however. Most experts predict that the US will import approximately 70 percent of its oil over the next 30 years unless there is a significant change in US energy policy (EIA, 2004).

To examine the effects of oil shocks on economic activity in the United States, we estimate Hamilton and Killian specifications using quarterly data from 1977 to 2008Q1. ${ }^{14}$ Tables 5 and 6 show that oil shocks have a negative and statistically significant on US GDP growth in all three specifications. Contrary to Brazil, the regression coefficients on lagged oil-price shocks do not change markedly when one controls for the level of the U.S. net import share and the level of oil intensity. However, the U.S. may be a special case since net imports have been trending higher while oil intensity has been falling, with the product of the two trends effectively yielding a flat line.

From the regressions in Tables 5 and 6, we estimate a series of counterfactual to examine the effects of reducing US imported oil share by increasing domestic production. The Bureau of Land Management (2008) has recently published a report that estimates the amount of oil and natural gas reserves -the equivalent of about 77 billion barrels of oil--in restricted areas such as Federal lands. The BLM reports that oil and natural gas reserves from these restricted areas could have reduced US oil import share to about 14 percent over the period 1975-2008Q1.

\footnotetext{
${ }^{14}$ Model (5') is still valid for the U.S., since in this case $w_{t}=0$ in the estimation sample. Kilian SVAR is also valid for the U.S. as it depends only on world-level variables: world oil production, global demand and world oil market prices.
} 
The counterfactual assumes that the United States uses all of its oil and natural gas reserves in the restricted areas during the period 1975-2008Q1. As shown in Figures 7a and 7b, the cumulative effect of reducing the US net oil import share to 14 percent would have increased GDP in the United States by about eleven percent, or 1.5 trillion dollars, over the last 33 years. US GDP is seven or eight percent higher if we make the strong assumption that there has been no change in energy intensity to accompany the increase in domestic energy production since the late 1970 s.

\section{Conclusion}

Should the United States increase domestic oil production? Should the United States develop alternative and renewable sources of energy? Although these questions have recently received quite a bit of attention in the press and Presidential Election given the recent rise in oil prices, there is little empirical evidence on the costs and benefits of these policies on economic growth. The absence of empirical evidence on this question can probably be attributed to the fact that G7 and OECD countries import a relatively constant share of oil and do not use alternative fuels as a major source of energy. Given these facts, we use Brazil as an historical experiment. Unlike any other major economy in the world, Brazil has reduced its share of imported oil from 70 to nearly 10 percent since the 1970 s oil shocks. The South American country has reduced its share of imported oil by: (1) increasing domestic oil production and (2) developing the world's largest clean, renewable alternative energy source that competes with gasoline at the pump, sugarcane ethanol.

We test the economic effects of these two energy policies on Brazilian economic growth extending models developed by Hamilton (1996) and Killian (2007) to include a country’s share 
of imported oil. We find that the accrued macroeconomic benefits of Brazil’s energy policies have been economically large and significant. Indeed, the empirical analysis suggests that Brazil's diversified energy policy has increased the country's GDP by approximately 35 percent (or, equivalently, $\$ 463$ billion) since 1980 . Without these changes in energy policies, Brazil’s economy would rank $15^{\text {th }}$ (behind Mexico) in terms of world GDP, rather than its current 2007 ranking of $10^{\text {th }}$. Notably, we find that three-quarters of the welfare benefits of the policy can be attributed to an increase in domestic oil production during a period of rising oil prices. Still, our results indicate that sugarcane ethanol has been successful in helping to partially insulate Brazil's economy from imported oil shocks. ${ }^{15}$ Under the counterfactual case of no ethanol program, the level of Brazil’s real GDP would be approximately 8 percent lower today, and business-cycle volatility would be approximately 2-5 percent higher.

Brazil’s energy programs raise important questions about the extent to which the United States should increase domestic oil production and develop alternative sources of energy. Since alternative energy sources in the U.S. account at the present time for only a small percentage of total energy consumption, we cannot specifically address this policy question. However, we can examine the hypothetical historical impact to the U.S. economy had the United States aggressively drilled all of the nation's oil and natural gas reserves. We simulate U.S. economic growth under the (admittedly controversial) assumption that energy companies were allowed to drill all of the oil and natural gas on the public lands between 1976 and 2008. Our analysis suggests that eliminating drilling restrictions on the public lands would have raised US GDP by approximately 11 percent, or 1.5 trillion dollars in 2005(USD), over the last 33 years. We interpret these economic benefits as an "upper bound" estimate since the counterfactual exercise

\footnotetext{
${ }^{15}$ Sugarcane ethanol has also reduced air pollution in Brazil's major cities. The environmental benefits of sugarcane ethanol are not considered in this paper. We leave this as an item for future research.
} 
assumes that the nation's improvements in energy intensity (i.e., oil consumed per unit of real GDP) was unaffected by this radical change in domestic oil production. We also find that US GDP would be seven or eight percent higher by increasing domestic production if we assume that energy efficiency has not changed since 1977.

Overall, our analysis suggests that increased domestic fossil fuel production could potentially have large economic benefits for the United States in the next 20 to 30 years. The results also suggest that the United States can not drill its way to energy independence. Alternative sources of energy such as nuclear, wind, solar, or others as well as innovations in fuel efficiency will eventually be needed so that the United States can more effectively reduce the negative effects of imported oil shocks on economic activity. 


\section{References}

Associação Nacional dos Fabricantes de Veículos Automotores, Various reports.

Bernanke, Ben S., 2004. “Oil and the Economy.” Speech delivered at the Distinguished Lecture Series, Darton College, Albany, GA, October 21. Available at http://www.federalreserve.gov/boarddocs/speeches/2004/20041021/default.htm

Bernanke, Ben S., Gertler, Mark, and Mark Watson, 1997. "Systematic Monetary Policy and the Effects of Oil Price Shocks.” Brookings Papers on Economic Activity, pp. 91-142.

DiPeso, Jim. 2003. "Foreign Oil Dependence Entangles US with Regimes that Finance Terror. Does Buying SUVS Promote Terrorism.” Detroit News, January 12.

Energy Information Administration, 2004. Long Term Oil Supply Scenarios. Washington, D.C.

Energy Information Administration, 2008. World Crude Oil Production.

Hamilton, James D., 1983. “Oil and the Macroeconomy Since World War II.” Journal of Political Economy 91: 228-248.

Hamilton, James D., 1985. “Historical Causes of Postwar Oil Shocks and Recessions.” Energy Journal 6: 97-116.

Hamilton, James D., 1996. “This is What Happened to the Oil Price-Macroeconomy Relationship.” Journal of Monetary Economics 38(2): 215-20.

Hamilton, James D., 2003. “What is an Oil Shock?” Journal of Econometrics 113: 363-98.

Hooker, Mark A., 2002. “Are Oil Shocks Inflationary? Asymmetric and Nonlinear Specifications Versus Changes in Regime.” Journal of Money, Credit and Banking 34 (May): 540-61.

Hooker, Mark A., 1996. "What Happened to the Oil-Price-Macroeconomy Relationship?” Journal of Monetary Economics 38: 195-213.

Instituto de Pequisa Economica Aplicada. www.ipea.gov.br

Inventory or Onshore Fedearl Oil and Natural Gas Resources and Restrictions to their Development. 2008. Washington: Bureau of Land Management, US Department of the Interior.

Johnson, Keith 2008. “Drill Baby Drill, If it Makes Economic Sense, That Is.” Wall Street Journal Blog, September 9.

Kilian, Lutz, 2008a. "Exogenous Oil Supply Shocks: How Big Are They and How Much Do They Matter for the U.S. Economy?” Review of Economics and Statistics 90:216-240. 
Kilian, Lutz, 2008b. "A Comparison of the Effects of Exogenous Oil Supply Shocks on Output and Inflation in the G7 Countries.” Journal of the European Economic Association 6: 78-121.

Kilian, Lutz, forthcoming. "Not All Oil Price Shocks Are Alike: Disentangling Demand and Supply Shocks in the Crude Oil Market.” American Economic Review.

Lashinshky, Adam and Nelson Schwartz. (2006). "How to Beat the High Cost of Gasoline Forever!” Fortune.

http://money.cnn.com/magazines/fortune/fortune_archive/2006/02/06/8367959/index.htm

Mort, Knut A., 1989. "Oil and the Macroeconomy When Prices Go Up and Down: An Extension of Hamilton’s Results.” Journal of Political Economy 91: 740-744.

Pickens, T. Boone. 2008. “This is My Plan for American Energy, What's Yours?” Wall Street Journal, September 2, A22.

Raymond, Jennie E. and Robert Rich, 1997. "Oil and the Macroeconomy: A Markov-State Switching Approach.” Journal of Money, Credit, and Banking 29: 193-213.

Schmitz, Troy, Seale, James L., and Peter Buzzanell. 2007. "Brazil’s Domination of the World's Sugar Market.” Arizona State University Working Paper. 
Table 1. Net Oil Import Share for the World's Ten Largest Economies:1980 vs. 2008 (in percent)

$\begin{array}{lccc}\text { Country } & 1980 & 2008 & \text { Change(Percentage Points) } \\ \text { Brazil } & \mathbf{7 0} & \mathbf{1 0} & \mathbf{- 6 0} \\ \text { Canada } & 13 & -5 & -18 \\ \text { France } & 98 & 98 & 0 \\ \text { Germany } & 93 & 95 & 2 \\ \text { Italy } & 96 & 88 & -8 \\ \text { Japan } & 100 & 100 & 0 \\ \text { Spain } & 94 & 100 & 6 \\ \text { United Kingdom } & 3 & 10 & 7 \\ \text { United States } & 33 & 60 & 27 \\ \text { Source: IMF, EIA } & & & \\ \text { Notes: Russia is not included in the table because of data constraints. }\end{array}$


Table 2. Hamilton Regressions for Brazil, 1980-2008Q1

\begin{tabular}{|c|c|c|c|}
\hline \multirow{3}{*}{$\frac{\text { Independent Variable }}{\text { GDP Growth(-1) }}$} & Column 1 & Column 2 & Column 3 \\
\hline & 0.073 & 0.138 & 0.138 \\
\hline & $(0.572)$ & $(0.284)$ & $(0.286)$ \\
\hline \multirow[t]{2}{*}{ GDP Growth(-2) } & -0.076 & -0.111 & -0.115 \\
\hline & $(0.050)$ & $(0.238)$ & $(0.214)$ \\
\hline \multirow[t]{2}{*}{ GDP Growth(-3) } & -0.191 & -0.19 & -0.187 \\
\hline & $(0.029)$ & $(0.036)$ & $(0.039)$ \\
\hline \multirow[t]{2}{*}{ GDP Growth(-4) } & -0.052 & -0.04 & -0.041 \\
\hline & $(0.630)$ & $(0.744)$ & $(0.740)$ \\
\hline \multirow[t]{2}{*}{ Energy Shock(-1) - $\mathrm{s}_{\mathrm{t}-1}$} & -0.054 & & \\
\hline & $(0.255)$ & & \\
\hline \multirow[t]{2}{*}{ Energy Shock(-2) $-\mathrm{s}_{\mathrm{t}-2}$} & 0.02 & & \\
\hline & $(0.455)$ & & \\
\hline \multirow[t]{2}{*}{ Energy Shock(-3) - $\mathrm{s}_{\mathrm{t}-3}$} & -0.001 & & \\
\hline & $(0.949)$ & & \\
\hline \multirow{2}{*}{ Energy Shock(-4) - $\mathrm{s}_{\mathrm{t}-4}$} & -0.009 & & \\
\hline & $(0.599)$ & & \\
\hline \multirow[t]{2}{*}{ Energy Shock weighted by Import Share $(-1)-\mathrm{s}_{\mathrm{t}-1}^{\mathrm{m}}$} & & -0.157 & \\
\hline & & $(0.129)$ & \\
\hline \multirow[t]{2}{*}{ Energy Shock weighted by Import Share $(-2)-\mathrm{s}_{\mathrm{t}-2}^{\mathrm{m}}$} & & 0.113 & \\
\hline & & $(0.051)$ & \\
\hline \multirow[t]{2}{*}{ Energy Shock weighted by Import Share $(-3)-\mathrm{s}_{\mathrm{t}-3}^{\mathrm{m}}$} & & -0.042 & \\
\hline & & (0.319) & \\
\hline \multirow[t]{2}{*}{ Energy Shock weighted by Import Share $(-4)-s^{m}{ }_{t-4}$} & & -0.063 & \\
\hline & & $(0.060)$ & \\
\hline \multirow[t]{2}{*}{ Energy Shock weighted by Import Share and Intensity $(-1)-\mathrm{s}_{\mathrm{t}-1}^{\mathrm{m}} \mathrm{i}_{\mathrm{t}-1}$} & & & -0.127 \\
\hline & & & $(0.142)$ \\
\hline \multirow[t]{2}{*}{ Energy Shock weighted by Import Share and Intensity $(-2)-\mathrm{s}_{\mathrm{t}-2}^{\mathrm{m}} \mathrm{i}_{\mathrm{t}-2}$} & & & 0.096 \\
\hline & & & $(0.045)$ \\
\hline \multirow[t]{2}{*}{ Energy Shock weighted by Import Share and Intensity $(-3)-\mathrm{s}_{\mathrm{t}-3}^{\mathrm{m}} \mathrm{i}_{\mathrm{t}-3}$} & & & -0.036 \\
\hline & & & $(0.295)$ \\
\hline \multirow[t]{2}{*}{ Energy Shock weighted by Import Share and Intensity $(-4)-\mathrm{s}_{\mathrm{t}-4}^{\mathrm{m}} \mathrm{i}_{\mathrm{t}-4}$} & & & -0.048 \\
\hline & & & $(0.085)$ \\
\hline \multirow[t]{2}{*}{ Inflation dummy - $\mathrm{D}_{\mathrm{t}}$} & 0.005 & 0.004 & 0.004 \\
\hline & $(0.204)$ & $(0.306)$ & $(0.304)$ \\
\hline R-squared & 0.09 & 0.136 & 0.134 \\
\hline P-value for F-Statistic of Energy Shocks & $(0.328)$ & $(0.028)$ & $(0.033)$ \\
\hline Observations & 109 & 109 & 109 \\
\hline
\end{tabular}

Note:p-values are in parenthesis 
Table 3. Kilian Regressions for Brazil, 1980-2008

\section{Independent Variable}

GDP Growth(-1)

GDP Growth(-2)

GDP Growth(-3)

GDP Growth(-4)

Energy Shock(-1) $-\mathrm{s}_{\mathrm{t}-1}$

Energy Shock(-2) $-\mathrm{s}_{\mathrm{t}-2}$

Energy Shock(-3) $-\mathrm{s}_{\mathrm{t}-3}$

Energy Shock(-4) $-\mathrm{s}_{\mathrm{t}-4}$

Energy Shock weighted by Import Share $(-1)-\mathrm{s}_{\mathrm{t}-1}^{\mathrm{m}}$

Energy Shock weighted by Import Share(-2) $-\mathrm{s}_{\mathrm{t}-2}^{\mathrm{m}}$

Energy Shock weighted by Import Share(-3) $-\mathrm{s}_{\mathrm{t}-3}^{\mathrm{m}}$

Energy Shock weighted by Import Share(-4) $-\mathrm{s}_{\mathrm{t}-4}^{\mathrm{m}}$

Energy Shock weighted by Import Share and Intensity $(-1)-\mathrm{s}_{\mathrm{t}-1}^{\mathrm{m}} \mathrm{i}_{\mathrm{t}-1}$

Energy Shock weighted by Import Share and Intensity $(-2)-s_{t-2}^{m} i_{t-2}$

Energy Shock weighted by Import Share and Intensity $(-3)-\mathrm{s}_{\mathrm{t}-3} \mathrm{i}_{\mathrm{t}-3}$

Energy Shock weighted by Import Share and Intensity $(-4)-s_{t-4}^{m} \mathrm{i}_{-4}$

$$
\begin{gathered}
\text { Column } 1 \\
\hline 0.115 \\
(0.350) \\
-0.101 \\
(0.353) \\
-0.196 \\
(0.028) \\
-0.041 \\
(0.708) \\
-0.092 \\
(0.027) \\
0.044 \\
(0.160) \\
0.002 \\
(0.924) \\
-0.013 \\
(0.462)
\end{gathered}
$$

-0.238
$(0.006)$
0.182
$(0.008)$
-0.047
$(0.358)$
-0.081
$(0.036)$

$-0.193$

(0.008)

0.152

$(0.008)$

$-0.04$

$(0.342)$

$-0.062$

$-0.058$

0.005

$(0.161)$

0.003

$(0.357)$

0.003

$(0.354)$

$\begin{array}{ccc}0.135 & 0.188 & 0.184 \\ 0.244 & 0.001 & 0.002 \\ 109 & 109 & 109\end{array}$

R-squared

P-value for F-Statistic of Energy Shocks

Observations

Note:p-values are in parenthesis 
Table 4. Brazil real GDP growth summary statistics: Actual vs counterfactual *

\begin{tabular}{|c|c|c|c|c|c|}
\hline \multirow{2}{*}{\multicolumn{2}{|c|}{$\begin{array}{r}\underline{\text { Data }} \\
1981 Q 1-2008 Q 1\end{array}$}} & \multicolumn{2}{|c|}{ Hamilton Counterfactual } & \multicolumn{2}{|c|}{ Kilian Counterfactual } \\
\hline & & Scenario 1 & Scenario $1+2$ & Scenario 1 & Scenario $1+2$ \\
\hline Mean & $2.5 \%$ & $2.2 \%$ & $1.3 \%$ & $2.2 \%$ & $1.1 \%$ \\
\hline Std dev & $7.9 \%$ & $8.1 \%$ & $9.2 \%$ & $8.3 \%$ & $10.1 \%$ \\
\hline CV & 3.1 & 3.6 & 6.8 & 3.7 & 9.3 \\
\hline \multicolumn{6}{|c|}{ 1995Q1 - 2008Q1 } \\
\hline Mean & $2.7 \%$ & $2.3 \%$ & $0.8 \%$ & $2.2 \%$ & $0.4 \%$ \\
\hline Std dev & $4.8 \%$ & $4.9 \%$ & $6.0 \%$ & $5.0 \%$ & $7.2 \%$ \\
\hline CV & 1.8 & 2.1 & 7.4 & 2.2 & 18.7 \\
\hline
\end{tabular}

* Note: two counterfactual scenarios,

Scenario 1: No Pro-Álcool Program $\left(w_{t}=0\right)$ and increased oil consumption from substitution of BTU-equivalent quantities of ethanol with oil $\left(\mathrm{m}_{\mathrm{t}}^{\mathrm{o}}=\mathrm{m}_{\mathrm{i}}^{\mathrm{o}+\mathrm{e}} \mathrm{t}\right)$.

Scenario 2: Increased net imports of oil from neglecting oil discoveries since 1980Q1 $\left(\mathrm{m}^{\circ}{ }_{\mathrm{t}}=\mathrm{m}_{80 \mathrm{Q} 1}^{0}\right)$. 
Table 5. Hamilton Regressions for United States, 1975Q1-2008Q2

\section{Independent Variable}

GDP Growth(-1)

GDP Growth(-2)

GDP Growth(-3)

GDP Growth(-4)

Energy Shock(-1) $-o_{t-1}$

Energy Shock(-2) $-\mathrm{o}_{\mathrm{t}-2}$

Energy Shock(-3) $-\mathrm{o}_{\mathrm{t}-3}$

Energy Shock(-4) $-\mathrm{O}_{\mathrm{t}-4}$

Energy Shock weighted by Import Share $(-1)-o_{t-1} m_{t-1}$

Energy Shock weighted by Import Share $(-2)-\mathrm{o}_{\mathrm{t}-2} \mathrm{~m}_{\mathrm{t}-2}$

Energy Shock weighted by Import Share(-3) $-\mathrm{o}_{\mathrm{t}-3} \mathrm{~m}_{\mathrm{t}-3}$

Energy Shock weighted by Import Share(-4) $-\mathrm{o}_{\mathrm{t}-4} \mathrm{~m}_{\mathrm{t}-4}$

Energy Shock weighted by Import Share and Intensity $(-1)-o_{t-1} m_{t-1} i_{t-1}$

Energy Shock weighted by Import Share and Intensity $(-2)-\mathrm{o}_{\mathrm{t}-2} \mathrm{~m}_{\mathrm{t}-2} \mathrm{i}_{\mathrm{t}-2}$

Energy Shock weighted by Import Share and Intensity $(-3)-o_{t-3} m_{t-3} i_{t-3}$

Energy Shock weighted by Import Share and Intensity $(-4)-0_{t-4} m_{t-4} i_{t-4}$

Inflation dummy - $\mathrm{D}_{\mathrm{t}}$

R-squared

P-value for F-Statistic of Energy Shocks

Observations

\section{Column}

0.214

$(0.010)$

0.068

$(0.525)$

0.016

$(0.865)$

$-0.052$

$(0.660)$

$-0.011$

(0.217)

$-0.006$

(0.330)

$-0.007$

(0.615)

$-0.011$

(0.003)

-0.021
$(0.349)$
-0.008
$(0.553)$
-0.009
$(0.728)$
-0.026
$(0.076)$

$-0.009$

(0.258)

$-0.004$

(0.435)

$-0.007$

(0.565)

$-0.01$

(0.004)

$-0.007$

(0.275)

$-0.007$

(0.274)

$-0.008$

(0.268)

0.17

(0.038)

134

0.151

(0.047)

134

Note:p-values are in parenthesis 
Table 6. Kilian Regressions for United States, 1975Q1-2008Q2

\section{Independent Variable}

GDP Growth(-1)

GDP Growth(-2)

GDP Growth(-3)

GDP Growth(-4)

Energy Shock(-1) $-o_{t-1}$

Energy Shock(-2) $-\mathrm{o}_{\mathrm{t}-2}$

Energy Shock(-3) $-\mathrm{o}_{\mathrm{t}-3}$

Energy Shock(-4) $-\mathrm{O}_{\mathrm{t}-4}$

Energy Shock weighted by Import Share(-1) $-\mathrm{o}_{\mathrm{t}-1} \mathrm{~m}_{\mathrm{t}-1}$

Energy Shock weighted by Import Share $(-2)-\mathrm{o}_{\mathrm{t}-2} \mathrm{~m}_{\mathrm{t}-2}$

Energy Shock weighted by Import Share $(-3)-\mathrm{o}_{\mathrm{t}-3} \mathrm{~m}_{\mathrm{t}-3}$

Energy Shock weighted by Import Share(-4) $-\mathrm{o}_{\mathrm{t}-4} \mathrm{~m}_{\mathrm{t}-4}$

Energy Shock weighted by Import Share and Intensity $(-1)-o_{t-1} m_{t-1} i_{t-1}$

Energy Shock weighted by Import Share and Intensity $(-2)-\mathrm{o}_{\mathrm{t}-2} \mathrm{~m}_{\mathrm{t}-2} \mathrm{i}_{\mathrm{t}-2}$

Energy Shock weighted by Import Share and Intensity $(-3)-o_{t-3} m_{t-3} i_{t-3}$

Energy Shock weighted by Import Share and Intensity $(-4)-0_{t-4} m_{t-4} i_{t-4}$

\begin{tabular}{c} 
Column \\
\hline 0.217 \\
$(0.009)$ \\
0.069 \\
$(0.513)$ \\
0.016 \\
$(0.871)$ \\
-0.055 \\
$(0.643)$ \\
-0.01 \\
$(0.249)$ \\
-0.006 \\
$(0.387)$ \\
-0.007 \\
$(0.635)$ \\
-0.011 \\
$(0.000)$
\end{tabular}

$-0.017$

$(0.424)$

$-0.01$

$(0.535)$

$-0.008$

$(0.788)$

$-0.028$

(0.034)

$-0.009$

$(0.282)$

$-0.004$

$(0.500)$

$-0.008$

$(0.599)$

$-0.01$

$(0.000)$

$-0.007$

(0.267)

$-0.007$

(0.266)

$-0.008$

$(0.261)$

0.168

(0.006)

134
0.151

(0.008)

134
0.168

(0.008)

134

Note:p-values are in parenthesis 
Figure 1. Net Oil Import Share for Brazil, 1975-2007

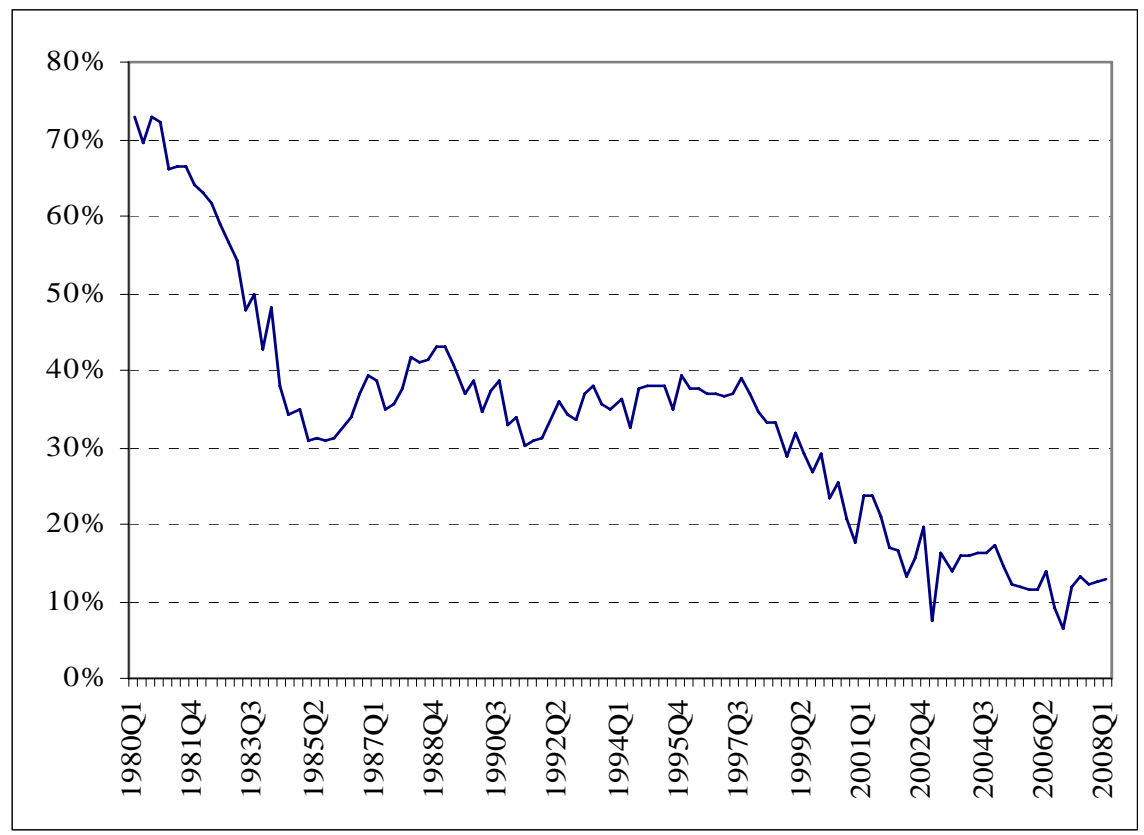

Source: IPEA, Brazil’s government, www.ipea.gov.br.

Figure 2. Ethanol Consumption Share in Brazil, 1975-2008Q1

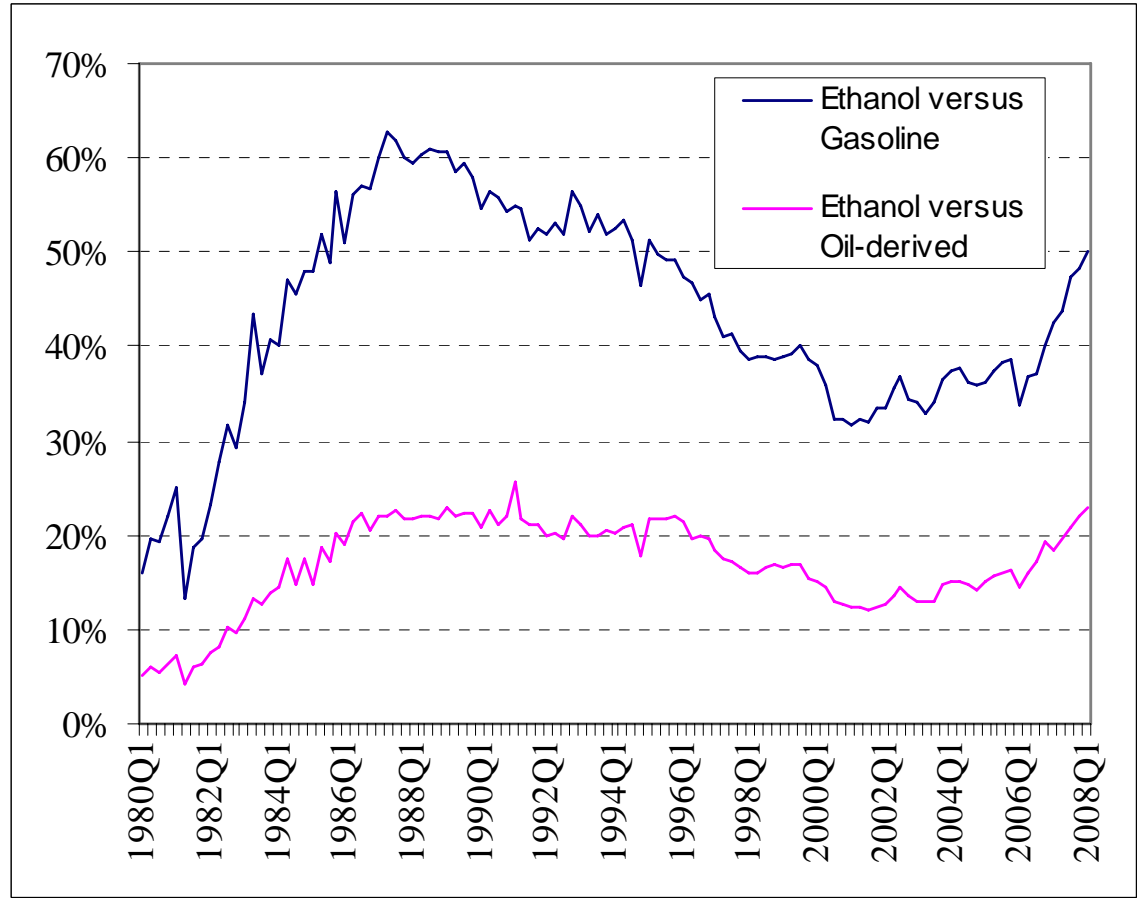

Source: IPEA, Brazil's government, www.ipea.gov.br .Original series are seasonally adjusted ethanol, gasoline and petroleum consumption (in thousand barrels a day). Petroleum consumption includes all petroleum-derived products such as fuel-oil, diesel-oil and gasoline however it excluded GLP, the category “others” and 25\% of gasoline. 
Figure 3. Ethanol Exports for Brazil, 1980-2008Q1

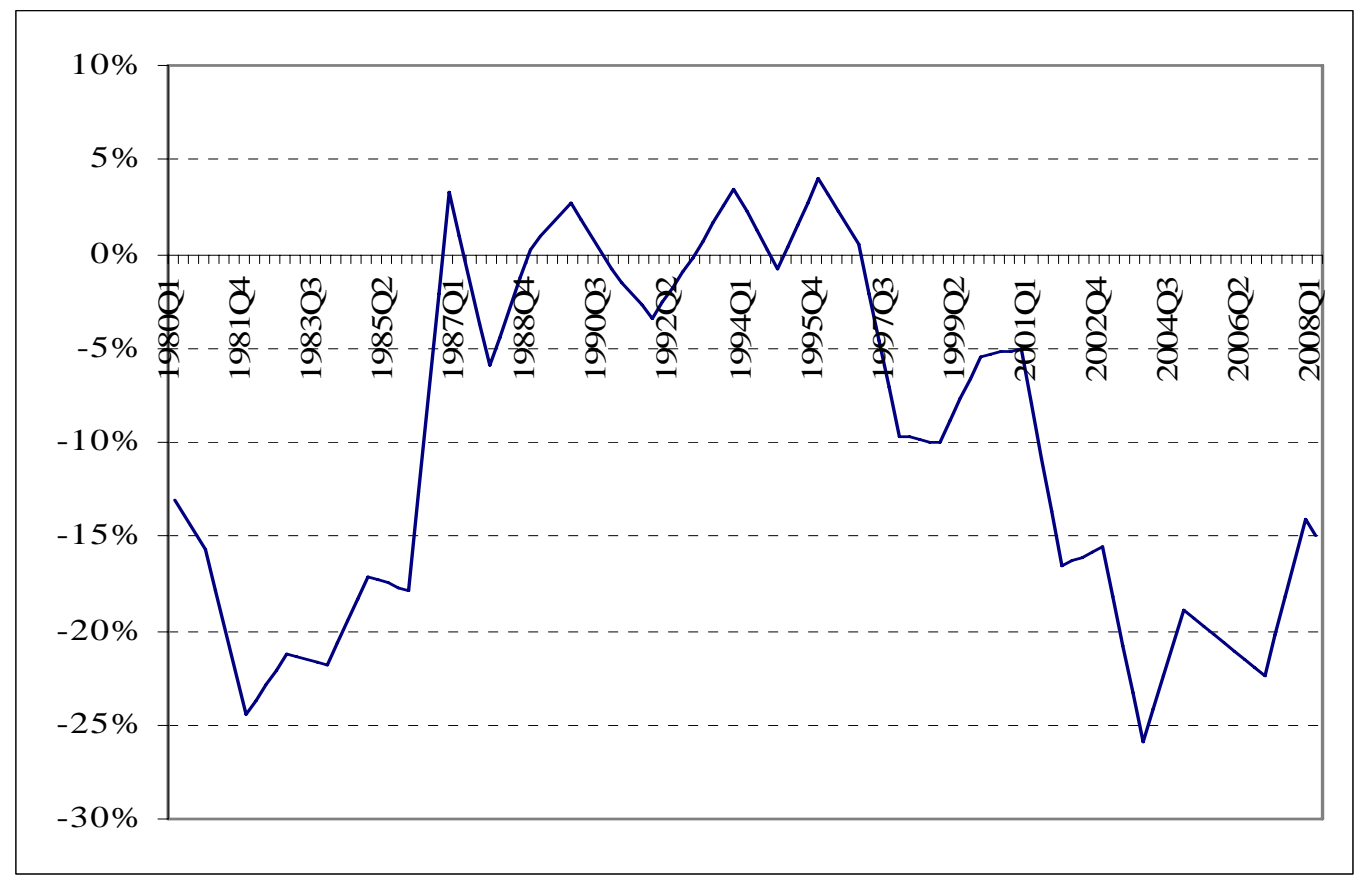

Source: IPEA, Brazil’s government, www.ipea.gov.br. 
Figure 4. Time-Varying Impact of Oil Shocks on Real GDP Growth in Brazil, 1980-2008*

\section{A. Hamilton Specification}

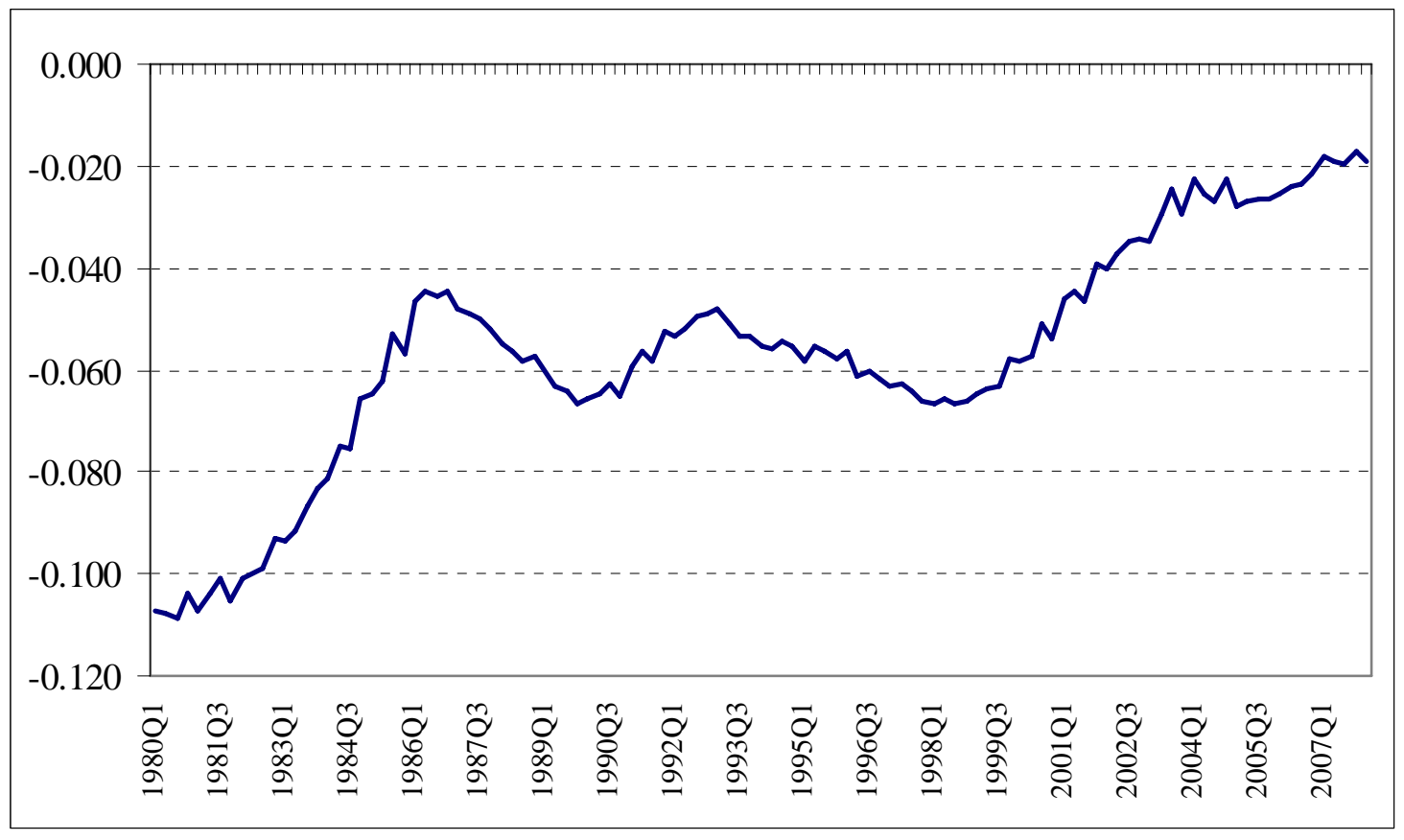

\section{B. Killian Specification}

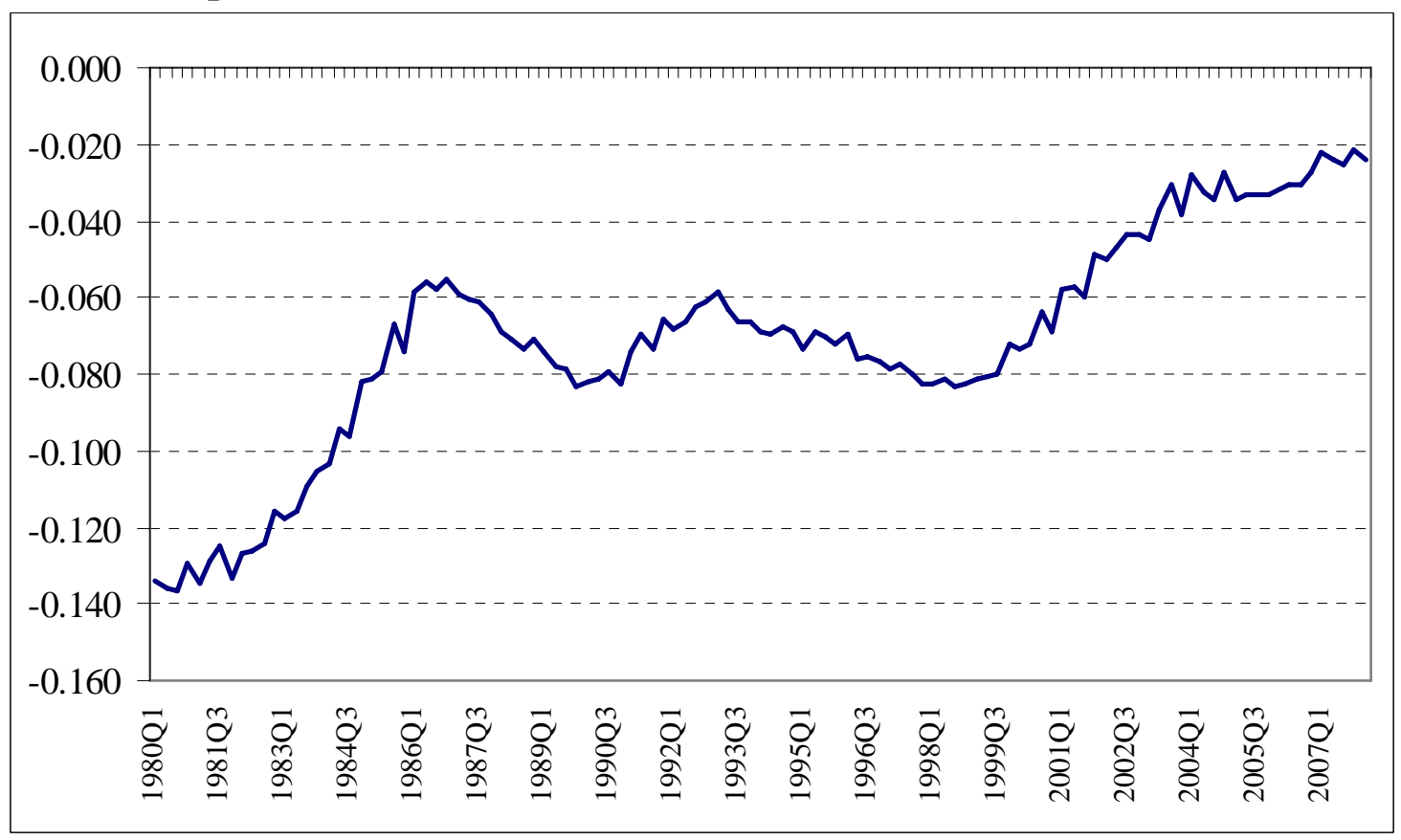

* Note: Time-varying impact estimated from regression (5') as $\sum_{i=1}^{4} \gamma_{i}\left(1-w_{t-i}\right) m_{t-i}^{o} i_{t-i}$ 
Figure 5. Counterfactual loss to level of Brazilian real GDP without energy programs

\section{A. Hamilton Specification using Import-Weighted Energy Shocks}

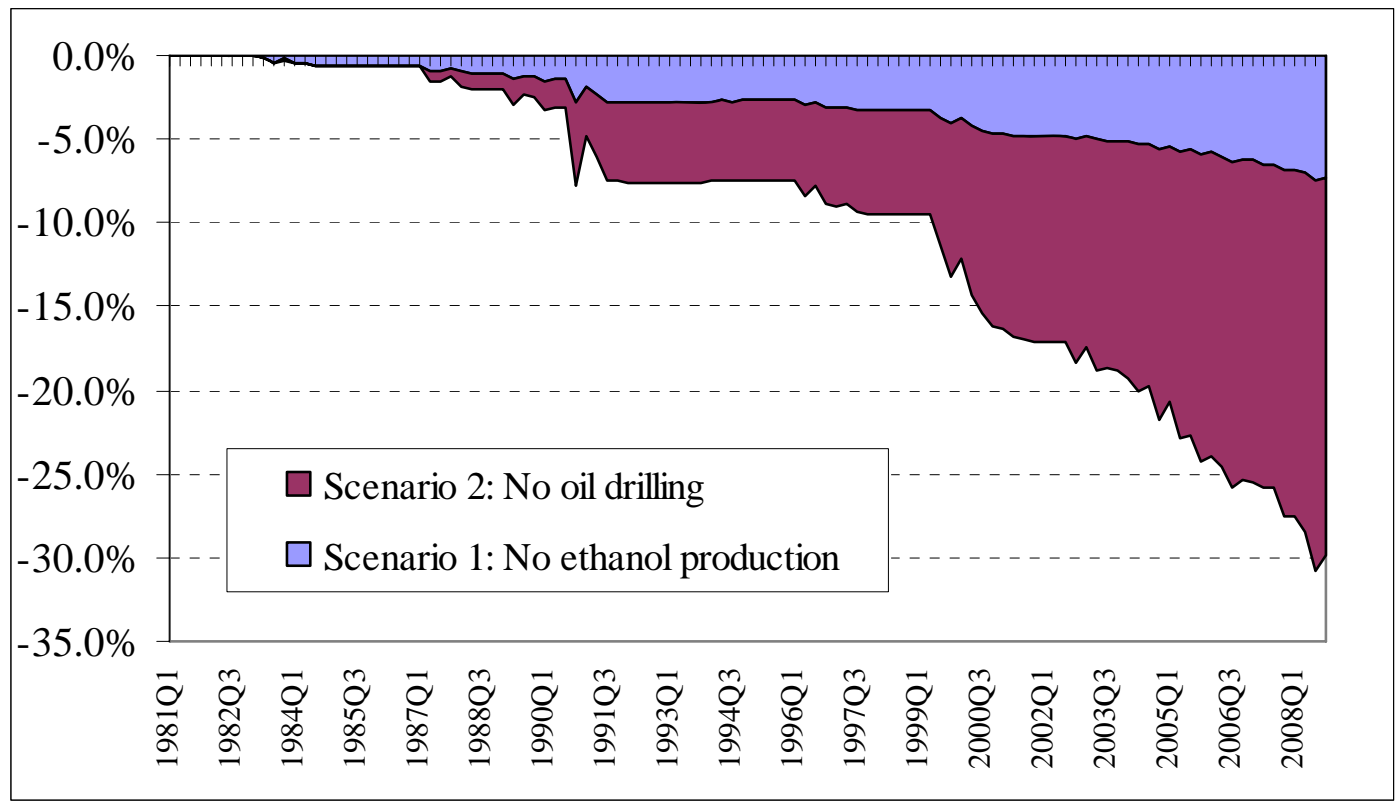

\section{B. Killian Specification using Import-Weighted Energy Shocks}

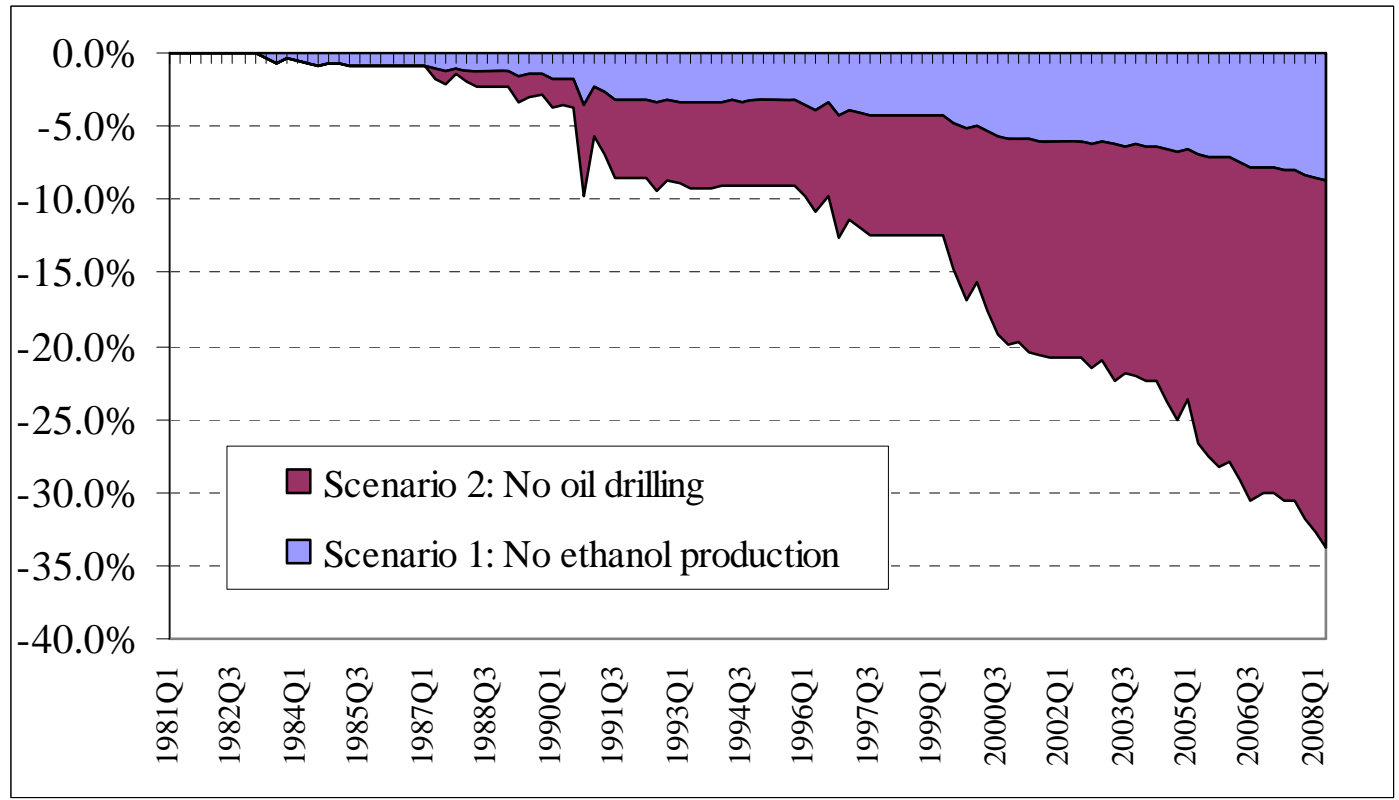

* Note: two counterfactual scenarios,

Scenario 1: No Pro-Álcool Program $\left(\mathrm{w}_{\mathrm{t}}=0\right)$ and increased oil consumption from substitution of BTUequivalent quantities of ethanol with oil $\left(\mathrm{m}_{\mathrm{t}}^{\mathrm{o}}=\mathrm{m}^{\mathrm{o}}{ }_{\mathrm{t}}\right)$.

Scenario 2: Increased net imports of oil from neglecting oil discoveries since 1980Q1 $\left(\mathrm{m}_{\mathrm{t}}^{\mathrm{o}}=\mathrm{m}_{80 \mathrm{Q} 1}^{\mathrm{o}}\right)$. 
Figure 6. United States Net Oil Import Share, 1975-2008Q1

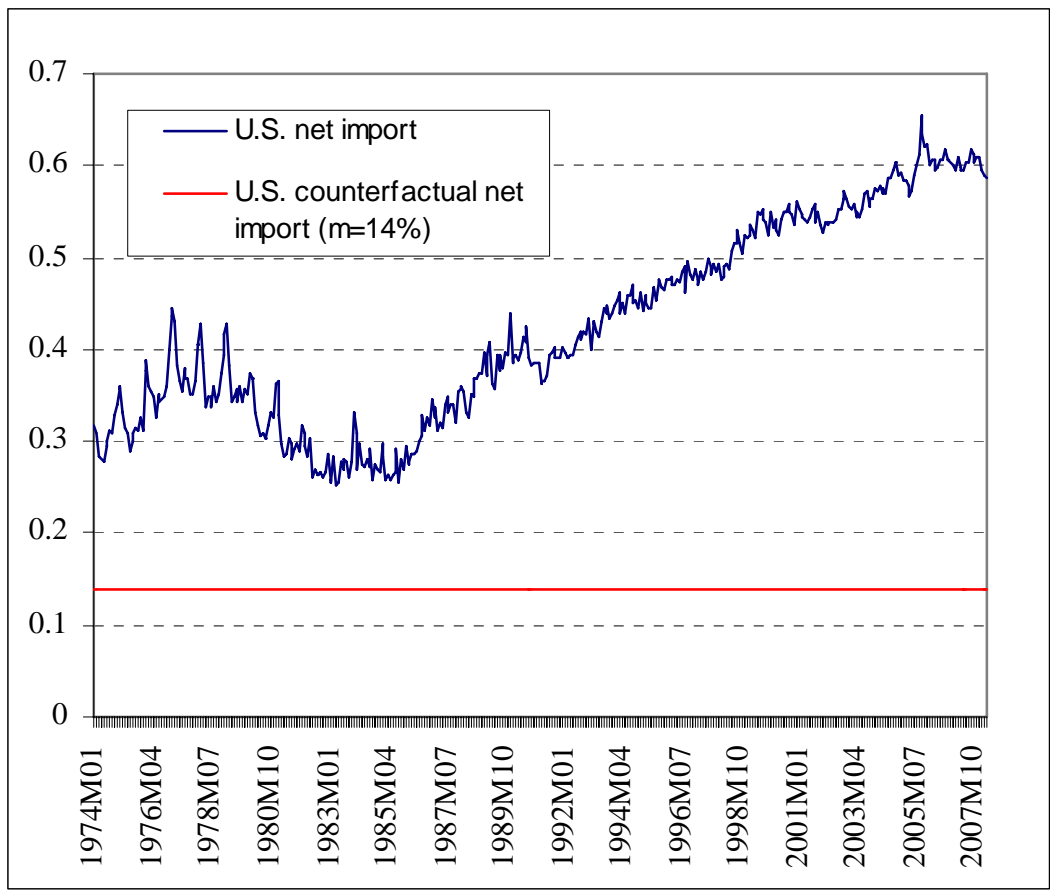

Source: EIA. 
Figure 7. Counterfactual gains to level of U.S. real GDP

\section{A. Hamilton Specification using Import-Weighted Energy Shocks}

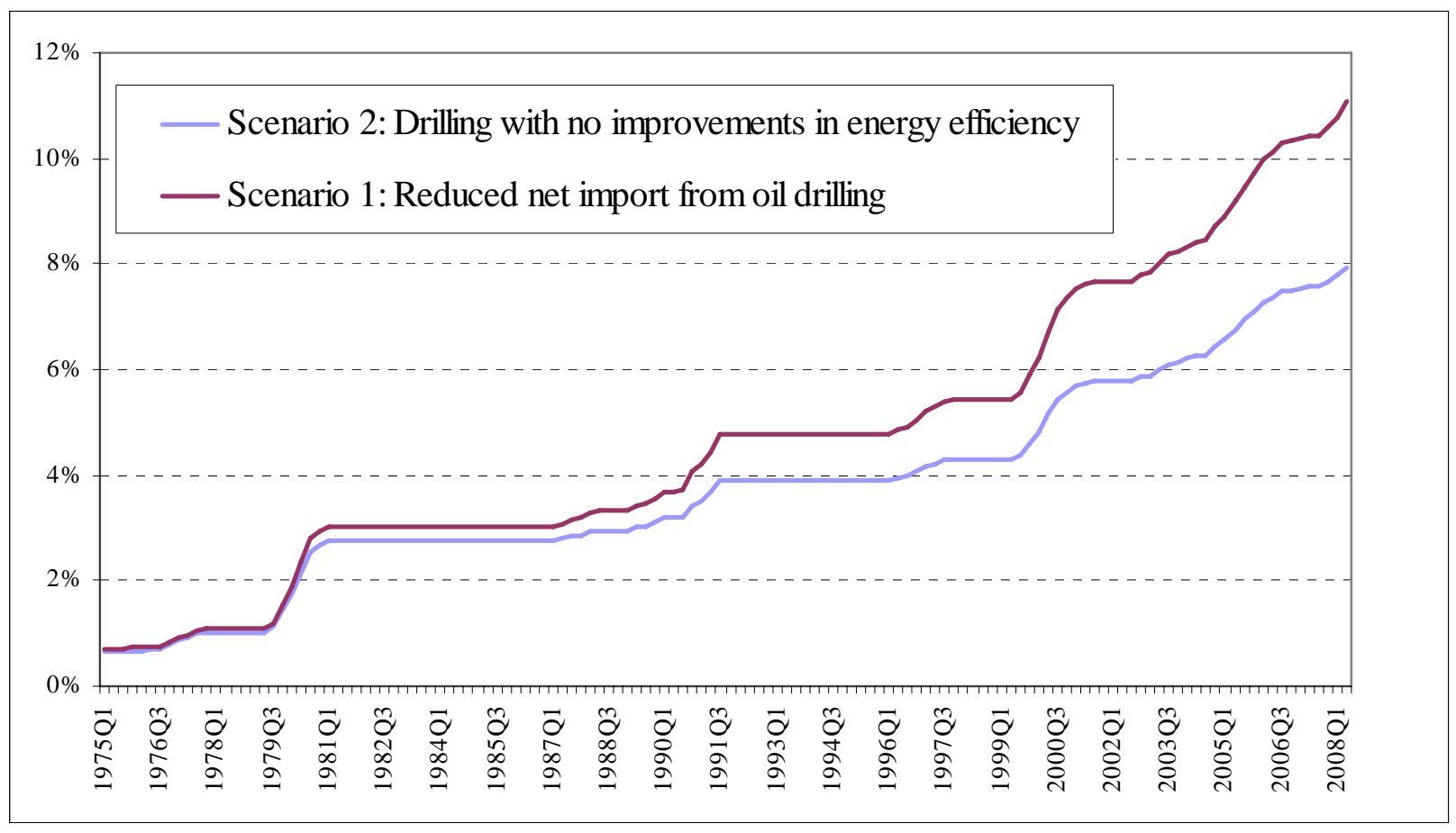

\section{B. Killian Specification using Import-Weighted Energy Shocks}

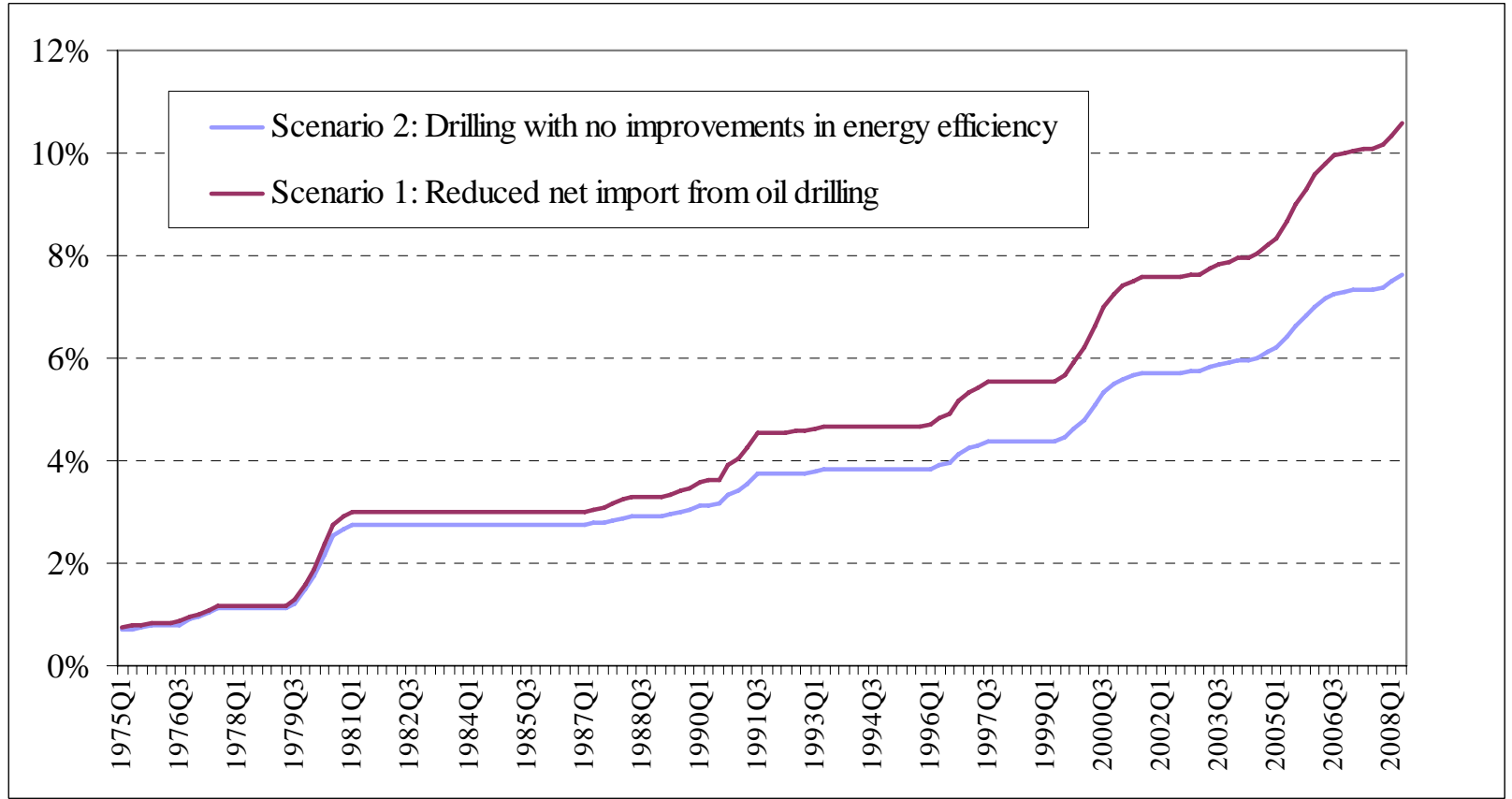

* Note: two counterfactual scenarios,

Scenario 1: Reduce U.S. net imports $(\mathrm{m}=14 \%)$ from tapping U.S. proven oil reserves from 1977 until complete depletion in 2008Q1 and assuming historical U.S. oil intensity (barrels per unit of GDP) is unchanged.

Scenario 2: Reduce U.S. net imports $(\mathrm{m}=14 \%)$ from tapping U.S. proven oil reserves from 1977 until complete depletion in 2008Q1 but neglecting improvements in U.S. energy efficiency $\left(i_{t}=i_{1975}\right)$. 


\section{Data Appendix.}

Figure A1. Petroleum real price indices: Raw data and Kilian SVAR

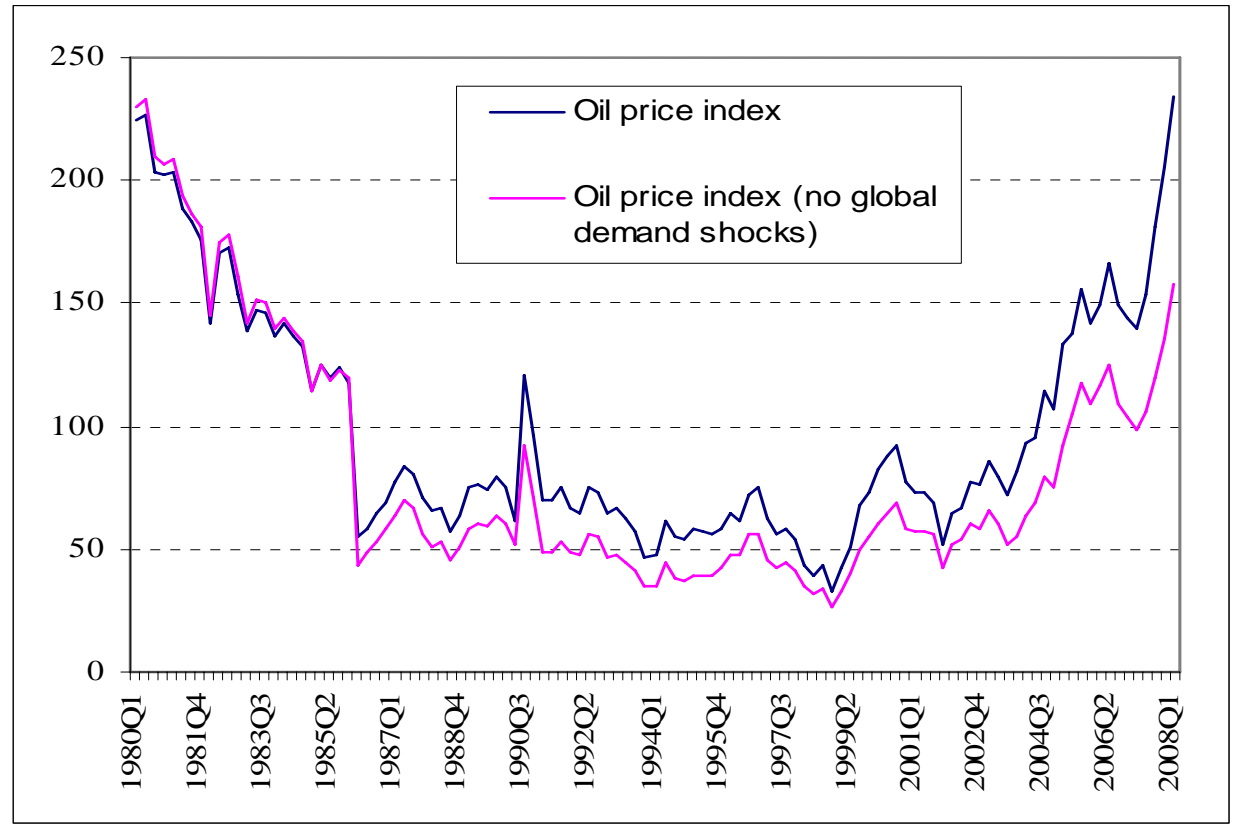

Note: Price indices 1975=100. Kilian SVAR series corresponds to the predicted value for oil prices from the SVAR plus two of the three structural shocks: supply and precautionary demand.

Figure A2: Brazilian net imports $\left(\mathrm{m}_{\mathrm{t}}{ }^{\mathrm{t}}\right)$ and counterfactual net imports $\left(\mathrm{m}^{0+\mathrm{e}} \mathbf{t}\right)$

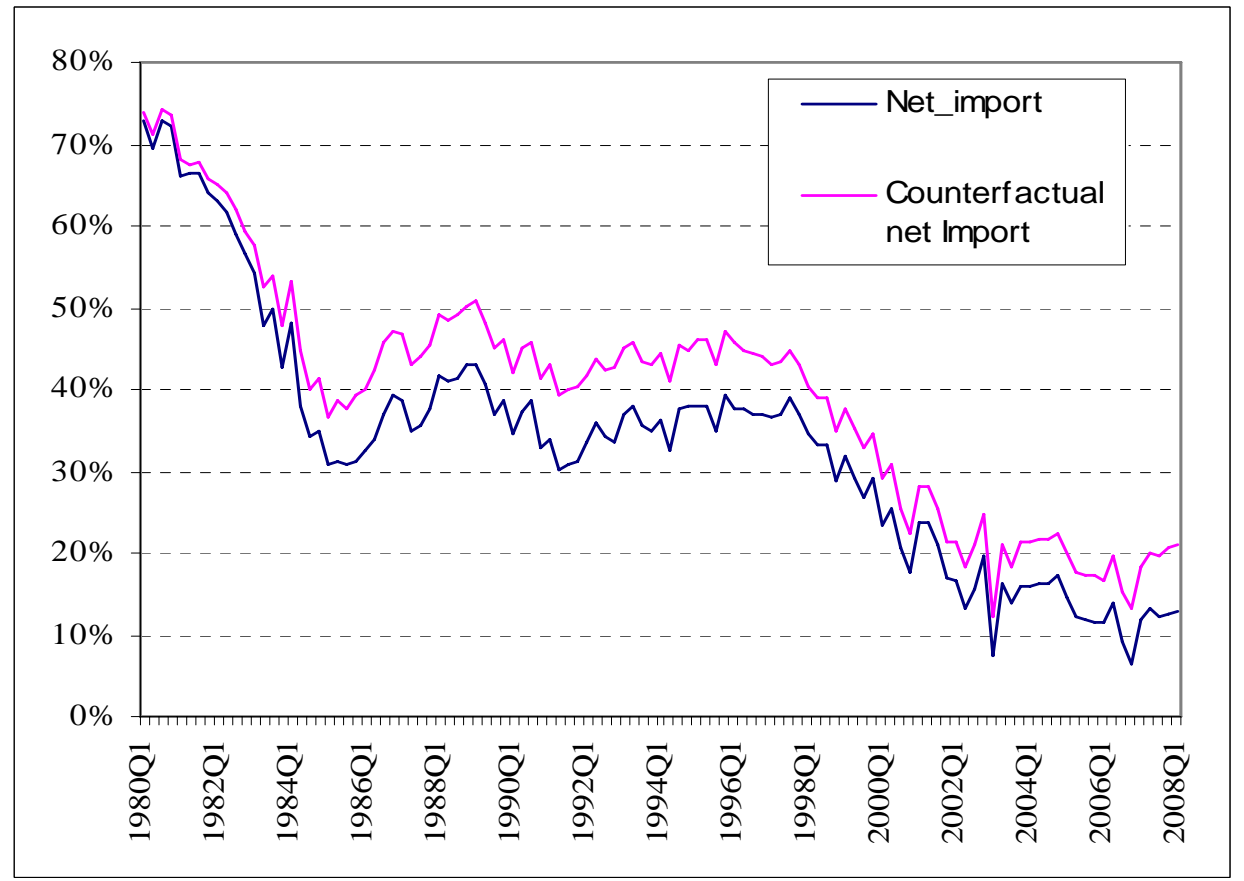

Source: IPEA, Brazil’s government, www.ipea.gov.br. 